

\title{
Urban collective garden participation and health: a systematic literature review of potential benefits for free-living adults
}

\author{
Marion Tharrey, Nicole Darmon
}

\section{To cite this version:}

Marion Tharrey, Nicole Darmon. Urban collective garden participation and health: a systematic literature review of potential benefits for free-living adults. Nutrition Reviews, 2021, 80 (1), pp.6-21. 10.1093/nutrit/nuaa147 . hal-03229527

\section{HAL Id: hal-03229527 \\ https://hal.inrae.fr/hal-03229527}

Submitted on 19 May 2021

HAL is a multi-disciplinary open access archive for the deposit and dissemination of scientific research documents, whether they are published or not. The documents may come from teaching and research institutions in France or abroad, or from public or private research centers.
L'archive ouverte pluridisciplinaire HAL, est destinée au dépôt et à la diffusion de documents scientifiques de niveau recherche, publiés ou non, émanant des établissements d'enseignement et de recherche français ou étrangers, des laboratoires publics ou privés. 


\section{COVER PAGE}

2 Article type: Lead Article

3 Title: Urban collective garden participation and health: a systematic literature review in free-

4 living adults

5 Author names: Marion Tharrey, Nicole Darmon

6 Author affiliations: MOISA, Univ Montpellier, CIRAD, CIHEAM-IAMM, INRAE, Institut

$7 \quad$ Agro, Montpellier, France

8 Corresponding author: Marion Tharrey

9 Mailing address: INRAE Montpellier, UMR MOISA Bât. 26, 2 place Pierre-Viala, 34060

10 Montpellier Cedex 1, France

11 Email: mariontharrey@hotmail.fr,

12 Telephone: +33499613003 .

13 Abstract

14 Context: Collective gardens are increasingly considered a tool to promote health and well-

15 being. Objective: In this systematic review, we critically appraise quantitative studies

16 exploring the potential health benefits of urban collective garden participation. Data Sources:

17 Articles published between January 2000 and August 2020 were used. Data Extraction: All original research studies reporting at least 1 health outcome associated with urban collective gardening in free-living adults from Western and other high-income countries were included. Of 1261 articles identified, 15 were included in the systematic review. Methodological quality was assessed by applying the criteria of the Quantitative Study Quality Assessment Tool. 
22 Analysis: A wide range of health indicators were used. Collective gardening was associated with higher fruit and vegetable consumption than was nongardening. Mixed results were found for physical activity and physiological health. A positive association was found in most studies with mental health and social health. However, the vast majority of included studies were cross-sectional and presented selection bias ( $\mathrm{n}=13$ of 15 for both) and very few used objective measurement methods $(n=3$ of 15$)$.

Conclusions: Longitudinal studies allowing the exploration of causal relationships are needed before the health benefits of collective garden participation suggested by existing studies can be confirmed.

Key words (3 to 5 key words or phrases); well-being; physical activity; fruit and vegetables; community garden; allotment garden.

Postprint version. Published in Nutrition Reviews : https://doi.org/10.1093/nutrit/nuaa147 


\section{INTRODUCTION}

In high-income countries, urban green spaces are recognized as key elements of sustainable cities because they provide unique opportunities to positively affect a wide range of health, social and environmental outcomes. ${ }^{1,2}$ As part of the trend towards more green areas in cities, a wide range of collective gardening initiatives have occurred in urban areas as a promising way to promote healthier lifestyles and create cohesive communities involved with their living environment. ${ }^{3}$ Collective gardens can be defined as cultivated spaces managed collectively by groups of gardeners and located at a distance from their homes. ${ }^{4}$ Community and allotment gardens are the most common forms of collective gardens in urban areas. Community gardens are plots of land grown collectively that are primarily intended to favour social links and intergenerational exchanges among the inhabitants of a neighborhood and to raise biodiversity awareness. ${ }^{5,6}$ Plots are rather small $\left(\leq 20 \mathrm{~m}^{2}\right.$ for individual plots $)$ and can be grown collectively or individually. ${ }^{7}$ Allotments gardens are pieces of land subdivided into larger plots (between 100 and $500 \mathrm{~m}^{2}$ ) rented to a person or a family for cultivation of their own fruit and vegetables and other produce, as well as for recreation purpose. ${ }^{8,9}$ Larger than community gardens, allotments are usually located in the urban periphery.

Gardening, in general, has been associated with a wide range of mental and social health outcomes, such as less mood disturbance, anxiety, depression as well as better life satisfaction, quality of life, sense of community and cognitive function. ${ }^{10,11}$ Gardening could also lower body mass index (BMI) by encouraging physical activity. ${ }^{10}$ In older adults, it may improve overall physical condition by increasing physical-strength and ability. ${ }^{11}$ Evidence of the positive impact of gardening on health comes from institutionalized settings (such as school, hospital, nursing home or health centre) ${ }^{12-16}$ however, less is known about the health effects of collective gardening in free-living urban adults. Authors of a recent review and meta-analysis found 
evidence of a beneficial effect of gardening in free-living adult populations in terms of BMI, nutrition and physical health compared to nongardeners, but this review did not look specifically at urban collective gardening. ${ }^{17}$ Findings of several literature reviews indicate that collective gardens have the potential to promote health and well-being by creating opportunities for fruit and vegetable cultivation, leisure, recreation and community cohesion. However, drawing firm conclusions on urban

collective gardens from these reviews is challenging because most of them did not distinguish between the results of quantitative and qualitative studies, ${ }^{18-23}$ targeted a specific country, ${ }^{18,24,25}$ or a specific population, ${ }^{23}$ studied nutritional outcomes only, ${ }^{21,24}$ did not use a systematic literature search. ${ }^{26,27}$ or were not specific to collective gardens (they considered vegetable production or urban gardens more generally). ${ }^{3,21,22,25}$ Furthermore none of these previous reviews provided insights on intensity and duration of gardening.

For the present systematic literature review, we set out to identify and critically appraises all the quantitative studies analyzing the relationship between participation in a collective garden and gardeners' health status in urban free-living adults in Western and other high-income countries, considering health as a state of complete physical, mental and social well-being, as defined by the World Health Organization. ${ }^{28}$

\section{METHODS}

The present systematic review was conducted according to the Preferred Reporting Items for Systematic Reviews and Meta-analyses (PRISMA) statement. ${ }^{29}$ The PRISMA checklist is provided as Appendix S1 in the Supporting Information online. 


\section{Literature search}

A systematic literature search was carried out using PubMed and Web of Science databases. The search strategy used a combination of comprehensive search terms, as follows: ("collective garden" OR “community garden" OR "urban garden” OR "shared garden” OR "allotment garden”) AND (“health" OR “well-being” OR “nutrition” OR “diet” OR “physical activity” OR “social” OR "leisure" OR "vegetable" OR "fruit" OR "stress" OR “depression" OR “anxiety").

\section{Inclusion and exclusion criteria}

The Population, Intervention, Comparison, Outcomes, and Study (PICOS) design criteria were used to identify all the quantitative research studies that examined the relationship between participation in an urban collective garden and health that were eligible for the present literature review (Table 1). All original articles in English, published in peer-reviewed journals from January 2000 to August 2020 and reporting $\geq 1$ health outcomes associated with urban collective gardening in free-living adults were included. Studies were excluded from the analysis if they 1) referred to gardening without additional details, home gardening, ornamental gardening or other forms of gardening not undertaken in a collective garden; 2) evaluated gardening programs performed in specific settings such as hospital, nursing home, health center, prison or refugee camp; 3) targeted participants younger that 18 years; 4) were carried out in rural areas or in developing countries; and 5) were based only on qualitative data. Literature reviews, case reports, theses and dissertations, letters, book chapters and authors' comments were also excluded. On the basis of the definition of the US 2000 Census, gardens were considered urban if they were located within areas that have a population density of $\geq 1000$ persons per square mile and a minimum total population of $50000 .{ }^{30}$ 


\section{Literature search strategy and data extraction}

Figure 1 presents the PRISMA flowchart describing the identification, screening, and selection process of the literature search. The literature search was conducted by the lead author and yielded 1261 records (after duplicate removal). The selection was done in 3 phases. First, title and abstract were screened and 1219 records not meeting the inclusion criteria of the review were excluded. When there was any doubt, the study was kept for additional scrutiny. Second, for the remaining records, full-text articles were screened, and 30 studies were excluded, yielding 12 full-text articles. Two studies, 1 indicated as urban without additional details, ${ }^{31}$ and the other with the majority of gardeners coming from urban area ${ }^{32}$ were included in the 12 identified studies. Another study in which data on people participating in community gardens or beautification projects were combined was also included in the 12 studies, because most participants were involved in both activities. ${ }^{33}$ Finally, 3 original research studies were added to the 12 studies on the basis of expert consultations and bibliographies of articles published by researchers, leading to a total of 15 articles included in the present literature review.

For each article, the following information was extracted: author names, year, setting, participant characteristics, sample size, study design, data collected, assessment tools, health outcomes and information on length and frequency of gardening (Table 2). ${ }^{31,32,41-45,33-40}$

\section{Quality assessment}

The methodological quality of the included studies was assessed using the Quantitative Study Quality Assessment Tool developed by the Effective Public Health Practice Project (EPHPP). ${ }^{46}$ The tool assesses 6 domains : selection bias, study design, confounders, blinding, 
data collection methods, withdrawals and drop-outs. According to the tool guidelines, each domain was rated as of "strong", "moderate", or "weak" quality. The quality assessment was performed independently by both authors. Disagreements were resolved by consensus.

\section{RESULTS}

\section{Study characteristics}

Eight of the 15 eligible studies were conducted in the United States, ${ }^{31,33-36,38,39,45} 6$ were conducted in in Europe ( 2 in the Netherlands, ${ }^{32,43} 1$ in the United Kingdom, ${ }^{37} 1$ in France, ${ }^{40} 1$ in Portugal, ${ }^{41}$ and 1 in Switzerland ${ }^{44}$ ), and 1 in Japan. ${ }^{42}$ In the studies conducted in the US and the one in France, researchers examined community gardens $(n=9)^{31,33-36,38-40,45}$ and the others allotment gardens $(n=6) .{ }^{32,37,41-44}$ One study targeted an elderly population ${ }^{37}$ and 3 studies targeted low-income populations. ${ }^{31,35,40}$ The mean age of collective gardeners ranged from 41 to 66 years. Sample size varied from 65 to 13133 with a mean number of collective gardeners of 91 .

Of the 15 studies included, 13 were cross-sectional, 1 was a post-test-only study ${ }^{45}$ and 1 a randomized control trial $(\mathrm{RCT}) .{ }^{43}$ In 11 studies, the comparison group comprised nongardeners ${ }^{31,32,34,40,42,45}$, home gardeners ${ }^{35,44}$ or both. ${ }^{36,38,39}$ Allotment and home gardeners were compared in 1 study to members of outdoor-walking groups and indoor-exercise groups. ${ }^{37}$ In another study, researchers compared community gardeners to participants of neighborhood association meetings, individuals participating in both gardens and association meetings, and individuals not participating in any of these activities. ${ }^{33}$ One study had no comparison group. ${ }^{41}$ The RCT compared 2 groups of allotment gardeners participating either in gardening activities or indoor reading. ${ }^{43}$ Regarding sampling, 2 studies used data from a representative survey of 
the general population, ${ }^{33,34} 4$ used multiframe sampling design to increase the proportion of gardeners, ${ }^{36,38,39,44}$. The other studies were based on convenience samples.

In terms of health outcomes, most of the articles examined physical health $(n=10)$, followed by mental health $(n=7)$ and social health $(n=6)$. Physical health was investigated through dietary behaviours $(n=5)$, anthropometric outcomes $(n=5)$ physical activity $(n=3)$, or other physical health outcomes $(n=4)$. In 3 of the 15 , researchers used objective measurement methods. ${ }^{37,40,43}$

\section{Collective gardening and dietary behaviours}

Gardeners' diets were examined in 5 studies, all of which were crosssectional. ${ }^{31,34,35,38,40}$ The main outcomes were fruit and vegetable intake, ${ }^{31,38}$ only vegetable intake, ${ }^{35}$ monthly household food supplies,${ }^{40}$ or soda and fast-food intake. ${ }^{31}$ Regarding the assessment tools, 3 studies used standardized questionnaires (the Behavioral Risk Factor Surveillance System questionnaire ${ }^{34,38}$ and the Food behavior checklist from Expanded Food and Nutrition Education Program ${ }^{35}$ ), 1 study used self-reported frequency of fruit, vegetables, soda and fast-food intake, ${ }^{31}$ and in 1 one study, researchers objectively recorded monthly household food supplies. ${ }^{40}$ Three studies were conducted in low-income populations. ${ }^{31,40,47}$

All studies observed a positive relation of collective garden participation on fruit and vegetable consumption. ${ }^{31,34,35,38,40}$ One study showed that community and home gardeners reported having doubled their vegetable intake as a result of gardening, to a level meeting the 2.5 daily servings recommended by the US Dietary Guidelines. ${ }^{35}$ In another study, researchers also found a higher frequency of vegetable consumption in collective gardeners than in nongardeners, although fruit, soda and fast-food frequency consumption did not differ. ${ }^{31}$ One US study based on a representative survey of the general population showed that adults with $\geq 1$ 
household member who participated in a collective garden consumed fruit and vegetables an average of 1.4 more times than individuals from nongardener households and were more likely to consume fruits and vegetables at least 5 times daily. ${ }^{34}$ Similarly, in another study, community gardeners were found to consume fruit and vegetables an average of 1 more times per day than nongardeners. ${ }^{38}$ Finally, the study recording household food supplies showed that the gardeners' supplies contained more fruit and vegetables than those of the nongardeners (approx. +158 g/day.person), whereas there was no difference for other food categories. ${ }^{40}$ In that study, the fruit and vegetables difference was mainly due to quantities purchased, the quantities produced in the garden averaging $28 \mathrm{~g}$ /day.person in the household (including potatoes and pulses). ${ }^{40}$

\section{Collective gardening and anthropometric outcomes}

In 5 studies, anthropometric outcomes were assessed using BMI as the only measure. ${ }^{35,37,39,42,45}$ Four studies were cross-sectional. ${ }^{35,37,39,42}$ Four studies estimated BMI on the basis of self-reported height and weight ${ }^{35,39,42,45}$ and one study used objective measurements. ${ }^{37}$

In 3 of the 4 cross-sectional studies, no significant difference in BMI was found between gardeners and the comparison group. Comparison groups used in these studies included home gardeners,${ }^{35}$ nongardeners, ${ }^{42}$ or members of outdoor-walking or indoor-exercising groups. ${ }^{37}$ Authors of another cross-sectional study observed a lower BMI among gardeners than nongardeners. ${ }^{39}$ In the post-test-only study, collective gardeners had a lower BMI than their same-sex siblings or neighbors (BMI range, -2.36 to -1.33 , calculated as $\mathrm{kg} / \mathrm{m}^{2}$ ), whereas no significant difference in BMI was observed with nongardening spouses of the gardeners. ${ }^{45}$ 
Collective gardeners' physical activity was examined in 3 studies. ${ }^{31,32,37}$ All were crosssectional and used questionnaires to assess physical activity. One study used 2 items from the Short QUestionnaire to ASsess Health enhancing physical activity, ${ }^{32}$ another one used a questionnaire that asked for self-reported frequency of moderate and vigorous physical activity questionnaire $^{31}$ and the short form of the International Physical Activity Questionnaire was used in the third study. ${ }^{37}$

A positive association between collective gardening and physical activity was reported in 1 study: gardeners, regardless of age, reported performing moderate physical activity more frequently than their neighbors, but only during the summer. ${ }^{32}$ Another study, conducted in a low-income population, found no difference in moderate and vigorous physical activity between collective gardeners and nongardeners. ${ }^{31}$ In the third study, conducted in an elderly population, intensities of physical activity and sitting time were similar between individuals performing community gardening, home gardening, walking outdoors or exercising indoors. ${ }^{37}$

\section{Collective gardening and other physical health outcomes}

In 4 studies, researchers assessed other physical health outcomes, namely self-perceived general health, ${ }^{10,31,32,37}$ subjective health complaints, ${ }^{10,32}$ physical constraints (limitation in the performance of several daily activities of low to vigorous intensity due to health condition), ${ }^{32}$ consultations with the GP, ${ }^{32}$ blood pressure ${ }^{37}$ and lung function. ${ }^{37}$ All studies were crosssectional. Self-perceived general health was measured with standardized questionnaires using a single-item ${ }^{10,31,32}$ or the physical section of the Quality of Life Questionnaire (short form-36, version 2, of the Health Survey). ${ }^{37}$ Physical constraints were assessed by the physical functioning subscale of the short form-36. ${ }^{32}$ Subjective symptoms were evaluated via a 
symptom checklist. ${ }^{10,32}$ Consultations with the general practitioner were also self-reported by participants. ${ }^{32}$ Blood pressure and lung function were measured. ${ }^{37}$

A positive association between gardening and $\geq 1$ physical health outcome was found in 2 studies. ${ }^{32,42}$ Regarding self-perceived general health, that collective gardeners reported better self-perceived general health and fewer subjective health complaints than nongardeners in 1 study, ${ }^{42}$ whereas in another study, no difference was found in self-perceived general health between gardeners and nongardeners in a low income population. ${ }^{31}$ In a study where the gardener sample was split according to age ( $<62$ years old and $\geqq 62$ years old.), the older gardeners only scored significantly better than nongardener neighbors of the same age category on physical constraints (locomotor activity limitation), subjective health complaints and consultation with general practitioner. ${ }^{32}$ Finally, in 1 study in which different leisure activities in an elderly population were compared, no differences were found in blood pressure, lung function, and general physical health among individuals participating in collective gardens, home gardens, outdoor-walking groups, or indoor-exercising groups. ${ }^{37}$

\section{Collective gardening and mental health}

Collective gardeners' mental health was examined in 7 studies through various indicators such as stress, ${ }^{32,37,43,44}$ psychological distress, ${ }^{31,42}$ life satisfaction, ${ }^{31,32}$ subjective happiness, ${ }^{41}$ mood, ${ }^{43}$ psychological well-being, ${ }^{31}$ individual empowerment, ${ }^{31}$ general mental health, ${ }^{37}$ and self-reported restoration. ${ }^{44}$ All were cross-sectional, except 1 RCT. ${ }^{43}$ All the studies relied on subjective measurements of mental health outcomes, except the RCT, in which salivary cortisol, a robust endocrine biomarkers of stress, was analyzed. ${ }^{43}$

All studies reported $\geq 1$ positive association between collective garden participation and mental health outcomes. In a study targeting a low-income population, researchers found that 
collective gardeners had greater psychological well-being and lower psychological distress than did nongardeners, whereas no significant difference was observed for individual empowerment and life satisfaction between groups. ${ }^{31}$ Similarly, in another study, psychological distress levels assessed with the General Health Questionnaire (a common measure of minor psychiatric disorders in the general population) were lower among collective gardeners than for nongardeners. ${ }^{42}$ In a study comparing different levels of collective garden attendance, researchers observed that greater attendance was associated with better subjective happiness among gardeners. ${ }^{41}$ Using structural equation model, 1 study showed that collective gardening was associated with a higher level of restoration (ie, stress-reducing effects of natural settings) through processes of perceived restorativeness. ${ }^{44}$ In comparing gardeners from different age groups, authors of 1 study reported that gardeners aged $\geq 62$ years reported less stress and better life satisfaction than both younger gardeners and nongardener neighbors. ${ }^{32}$ Compared to indoor exercising, collective gardening was also associated with lower perceived stress in elderly population, although there was no difference in general mental health between groups. ${ }^{37}$ The beneficial effect of collective gardening on short-term restoration from stress suggested by the cross-sectional studies, was supported by the experimental study. In the RCT, stress-relieving effects of 30-min session of outdoor gardening was compared with indoor reading (within gardeners' plot) after performing a stressful task. ${ }^{43}$ The outdoor gardening activity was found to induce a greater decrease in salivary cortisol and a higher increase in self-reported positive mood than the indoor reading. ${ }^{43}$ Finally, gardening (in general) can also be a source of stress as suggested by 1 study, although in this study, collective gardeners reported less garden-related stress than did home gardeners. ${ }^{44}$ 
The relation between the social health and collective gardening was examined in 6

273 studies through various indicators such as perceived social support, ${ }^{37}$ neighborhood attachment,${ }^{36}$ social cohesion, ${ }^{42}$ loneliness, ${ }^{32}$ contact with friends, ${ }^{32}$ social capital, ${ }^{33}$ neighborhood norms and values, ${ }^{33}$ sense of community, ${ }^{31}$ and community and organisational empowerment. ${ }^{31}$ All the studies were cross-sectional and relied on subjective measurement of social health outcomes.

Five of the 6 reported $\geq 1$ positive association between collective garden participation and social health outcomes. ${ }^{31-33,36,42}$ Collective gardeners from a low-income population reported higher sense of community, community empowerment and organizational empowerment than did nongardeners. ${ }^{31}$ One study showed that collective gardeners had better social cohesion than nongardeners. ${ }^{42}$ Authors of another study also found a higher level of neighborhood attachment among gardeners than in nongardeners. ${ }^{36}$ Similarly, 1 study based on a representative survey of the general population showed that adults with at least one household member who participated in community gardens or beautification projects reported higher levels of bonding and linking social capital, as well as stronger neighborhood norms and values (such as neighborhood involvement, satisfaction or collective efficacy) compared to individuals from households who neither participated in these activities or in neighborhood meetings. ${ }^{33}$ In 1 study, collective gardeners aged $\geq 62$ years reported less loneliness than did nongardener neighbors from the same age group, whereas no similar difference was found between younger groups of gardeners and nongardeners. ${ }^{32}$ In the same study, collective gardeners aged $\geq 62$ years also reported more frequent contact with their friends compared to younger ones, whereas no such difference was found in nongardener neighbors. ${ }^{32}$ Conversely, another study comparing different leisure activities in an elderly population found no difference in social support between 
collective gardeners, home gardeners and members of outdoor-walking groups or indoorexercising groups. ${ }^{37}$

\section{Length and frequency of gardening}

Length of gardening time was specified in 4 studies and ranged from $<1$ month to 20 years..$^{32,35,40,45}$ None of the studies evaluated the effect of length of gardening on health outcomes.

Frequency of gardening was specified in 5 studies, and ranged from every day to less than once a month. ${ }^{31,32,41,42,44}$ In 1 study, frequency and duration of gardening were not associated with any of the investigated health outcomes. ${ }^{42}$ Conversely, in 1 study, researchers reported higher levels of happiness among collective gardeners who visited the garden daily than for those visiting the garden less regularly. ${ }^{41}$ Another study also showed that the effect of gardening frequency differed across health outcomes: regular participants going to the garden $>12$ times per year reported more sense of community, whereas occasional participants reported higher vegetable intake. ${ }^{31}$ The relationship between frequency of gardening and health outcomes also depended on the type of activities performed in the garden. One study found a positive relationship between well-being and percentage of time spent on gardening and maintenance activities relative to time spent sitting, reading and enjoying the garden. ${ }^{32}$ Finally, gardening frequency was assessed in 1 study, but researchers not evaluate its association with health outcomes. ${ }^{44}$ 
Results of the quality assessment for each of the 6 domains of the EPHPP (ie, selection bias, study design, confounders, blinding, data collection methods, withdrawals and drop-outs) are presented in Table 3. ${ }^{31,32,41-45,33-40}$ Selection bias (first EPHPP domain) was likely in many studies. Two studies, using respectively, a random sampling method with high level of participation $^{33}$ and population databases ${ }^{45}$, were at moderate risk of selection bias; the others studies based on a random sampling method but with participation rate $<60 \% \%^{34,36,38,39,44}$ or based on convenience samples ${ }^{31,32,35,37,40-43}$ were rated as weak. Regarding study design (second EPHPP domain), the $\mathrm{RCT}^{43}$ and the post-test-only study ${ }^{45}$ were respectively rated as strong and moderate, whereas the other studies were considered weak because of their cross-sectional design. In terms of confounders (third EPHPP domain), the majority of studies controlled for potential confounders and were rated as strong $(n=9)^{32-34,36,38,39,42-44}$ or moderate $(n=2) .31,45$

Regarding blinding (fourth EPHPP domain), 4 studies used data from population-based surveys and were rated as moderate because participants were not aware of the research question. ${ }^{34,36,38,39}$ The other studies were rated as weak. In terms of data collection methods (fifth EPHPP domain), studies mainly used widely used and well-established self-reported assessment tools and, therefore, were rated as strong $(n=9)^{33,34,36-38,41-44}$ or moderate $(\mathrm{n}=$ 6). ${ }^{31,32,35,39,41,45}$. The withdrawals and drop-outs assessment (sixth EPHPP domain) was applicable only to the $\mathrm{RCT}^{43}$ and the post-test-only study, ${ }^{45}$ which were rated as strong.

\section{DISCUSSION}

A total of 15 quantitative studies on the relationships between urban collective garden participation and health status in free-living adults from western and other high-income countries were identified and included in this literature review. Half of them $(n=7)$ were 
published in the past 5 years, with only 1 published before 2010, showing a recent but growing scientific interest in collective gardens as tools to promote the health and well-being of urban dwellers.

The health status of gardeners was assessed in its physical, mental and social dimensions. Although some conclusions diverge, all the studies demonstrated a positive association between collective gardening and at least one health indicator, suggesting that gardeners benefit from physical and social environment, and psychological conditions conducive to health and well-being. The frequency of fruit and vegetable consumption and participants' BMI were the most investigated variables. A positive association was observed between collective gardening and fruit and vegetable consumption..$^{31,34,35,38,40}$ It is hypothesized that gardening, by increasing the ready availability of fresh produce from the garden, encourages the consumption of fruit and vegetables. However, in the study objectively measuring the quantity of produce from the collective garden in monthly household food supplies, this quantity was negligible and the higher fruit and vegetable supplies observed in gardeners' versus nongardeners' households were due to more purchases of those items. ${ }^{40}$ Additional studies are needed to ascertain whether the higher consumption of fruit and vegetables among gardeners is due to the produce from their gardens or to healthier behaviors that the gardeners already had beforehand or developed through gardening. Regarding BMI, conflicting results were obtained : in 2 studies gardening was inversely associated with BMI, ${ }^{39,45}$ whereas no association with BMI was found in 3 studies. ${ }^{35,37,42}$ For the other indicators of physical health, the limited number of studies and their conflicting results make it difficult to draw conclusions about the beneficial effect of collective gardening. Moreover, the findings of the present review suggest that collective garden participation has the potential to enhance mental well-being by its positive relationship with life satisfaction, happiness and restoration, and its inverse relationship with level of stress and mood disturbance. Collective gardening is 
also likely to enhance social health and community cohesion by its positive effect on social capital, social cohesion, sense of community, community empowerment or neighborhood attachment.

The quality assessment of the included studies highlighted methodological weakness of the existing literature on collective garden participation and health of urban adults. Because cross-sectional design does not allow for causal assessment, it is not possible to determine whether observed differences between gardeners and nongardeners were due to a selection bias. . Namely, it is possible that the gardeners surveyed in the cross-sectional studies are those who have persevered in the gardening activity and therefore present different characteristics from the general population, such as being already committed to healthy eating, regular physical activity, frequent contact with the natural environment, and social relations. Causality is an essential concept in public health to understand the impact of an intervention on outcomes, contributing to the implementation of effective programmes or policies that promote population health and well-being. ${ }^{48}$ Another cause of weakness in almost all the studies was the use of selfreported questionnaires subject to desirability and memory bias. ${ }^{49}$ Fruit and vegetable consumption, in particular, was assessed by short questionnaires. Although such questionnaires can collect large amounts of data from large samples rapidly and cost-effectively, they lack precision, ${ }^{50}$ and their validity remains moderate ${ }^{51}$ No study used rigorous methods of dietary assessment (eg, multiple 24-hour recalls) or biomarkers of fruit and vegetable intake. Besides, no study directly assessed physical activity and sedentary behaviours using direct measures (such as activity monitors, heart rate monitors or pedometers). Objective measures of physical activity are more accurate than questionnaires at predicting sedentary behavior, because they provide a more robust assessment of energy expenditure and levels of physical-activity intensity, especially of light activity. ${ }^{52-55}$ Such measures should be preferred to assess the impact of lifestyle-related physical activity interventions in free-living conditions. ${ }^{55}$ 
An increasing number of experimental studies have been conducted to evaluate the beneficial effects of different forms of gardening on health, although, so far, none has focused on urban collective gardens. In school settings, several gardening interventions were effective at improving children's fruit and vegetable consumption, knowledge and attitudes towards fruit and vegetables, BMI, waist circumference as well as physical activity and academic performance. ${ }^{14}$ Home gardening was also shown to be an effective way to improve fruit and vegetable consumption and physical performance among cancer survivors, ${ }^{56,57}$ and horticultural therapy improves cognitive function, agitation, positive emotion and engagement in people suffering from mental health problems. ${ }^{15,16}$

Two longitudinal studies have been recently carried out in France ${ }^{58}$ and the US. ${ }^{59}$ to explore the causal relationships between community gardening and health of urban adult populations using rigorous quantitative methods to assess diet and physical activity. While the results of the US study are yet not available, those of the French have just been published. ${ }^{58}$ This quasiexperimental study found no positive impact of the first year of community gardening on healthiness of household's food supplies, physical activity, BMI, mental well-being and social health, connection to nature, sensibility to food waste, as well as, the environmental impact and expenditure of food purchased. Qualitative interviews revealed several barriers to the participation such as lack of time, lack of gardening knowledge, physical difficulty of gardening, health problems and conflicts with other gardeners, possibly explaining the lack of impact and confirming the importance of mixing quantitative and qualitative approaches in intervention research studies.

The results of this systematic literature review suggest that collective gardening could help meeting recommended consumption of fruit and vegetables in low-income populations. ${ }^{31,40,47}$ This is consistent with findings from a previous literature review in which the authors evaluated the benefit of community gardens on health and wellbeing amongst vulnerable populations, 
especially socially disadvantaged individuals or households, ethnic minorities and refugees. ${ }^{23}$ In the latter review, which mixed urban and rural settings, different age groups and quantitative and qualitative methods, most of the studies were carried out in the US. Because of strong economic, physical, and social disparities in US neighborhood environments, disadvantaged populations and minorities have low access to healthy and affordable foods, as well as recreation facilities ${ }^{60,61}$; thus, community gardens may be a key tool to tackle health inequities in such a context. Nevertheless, a survey conducted on food-insecure households in Toronto, Canada revealed that very few of these households take advantage of the community gardens because they considered that gardening programs are not suited to their busy schedules, interests, or needs. ${ }^{62,63}$ More studies are needed on populations of different socioeconomic status and in various settings to extend the existing literature.

Several interventions with elderly people in nursing homes have shown a positive effect of gardening on loneliness, ${ }^{64}$ stress, ${ }^{65}$ depression, ${ }^{66,67}$ quality of life, ${ }^{64,66}$ relationships with others, ${ }^{66,68}$ sense of community, ${ }^{64}$ and physical performance, ${ }^{65,67}$ as well as markers of chronic diseases. ${ }^{68,69}$ Studies evaluating therapeutic gardening programs were nevertheless excluded from this review to better assess the effect of collective gardening on healthy urban dwellers in free-living conditions. One study in the review highlighted the potential contribution of collective gardens to an active and healthy lifestyle, especially among the elderly, ${ }^{32}$ albeit the cross-sectional design did not allow for causal inference. Conducting interventions in noninstitutionalized settings is necessary to evaluate if collective gardening can promote healthy aging of urban dwellers by limiting risks of chronic health conditions, physical decline, mental disorders and social isolation.

Compared to gardening in institutionalized settings, where the activity is supervised and scheduled weekly, participation in a collective garden depends mainly on spare time of each individual. The results showed that frequency of gardening was highly variable and ranged from 
an everyday routine to a few visits per year. It may be that the longer the exposure to a collective garden, the greater the effect will be, and so the impact of collective gardening on health status will depend on the frequency of the activity. However, the level of gardening required to see a health benefit cannot be clearly determined from the literature, and the few studies investigating the health effect of length of gardening or frequency of gardening have yielded inconsistent results. ${ }^{31,41,42}$ More research is needed to understand the roles of duration and frequency of gardening exposure in inducing health benefits. ${ }^{70}$

\section{Strength and limitations}

Several previous literature reviews have addressed the health effects of gardening through different formats of gardening and within various populations. To our knowledge, the present review is the first to provide a critical appraisal of all the quantitative literature (available until August 2020) on urban collective gardening and health in free-living adults from western and other high-income countries. One strength of this review is the use of a systematic approach based on the PRISMA methodology. To better evaluate the potential of collective gardens as tools to promote the health of urban dwellers, narrow inclusion criteria were used, which resulted in the exclusion of studies that mixed collective and home gardens, ${ }^{71}$ rural and urban areas, ${ }^{72}$ or that were not carried out in an urban area as defined by the US 2000 Census. ${ }^{73}$ Studies from low-income countries were also excluded collective gardens are being used to support communities' livelihood rather than for recreational or educational purposes. ${ }^{74}$ Because several therapeutic and school gardening programs have proven their effectiveness in improving participant's health and well-being, ${ }^{12-16}$ the present review was restricted to studies conducted on data from free-living urban adults, and for this population, but limited evidence of health benefits of urban collective gardening was found. 
Another strength of this review is the evaluation of the methodological quality of included studies, using the EPHPP assessment tool. The EPHPP assessment tool has both content and construct validity ${ }^{75,76}$ and was judged to be an appropriate tool to be used in the systematic review of non-randomised studies. ${ }^{46,77}$ Although EPHPP assessment tool was designed to evaluate a range of study designs of various public health topics, it might not be fully appropriate to adequately discriminate the quality of complex community-based interventions such as the ones on gardening, which cannot be blinded, can hardly reach a high participation rate, have inherent selection bias (ie. participants must be interested in gardening), and generally assess multiple outcomes.

\section{CONCLUSION AND RESEARCH DIRECTIONS}

The literature on the relationship between collective garden participation and gardeners' health and well-being in free-living urban adults remains limited. Several studies have found a positive association between collective garden participation and physical, mental or social health, but the results come mostly from cross-sectional studies. Experimental or quasiexperimental studies with presence of a control group, sufficiently large samples, validated measurement methods and dose-response analysis are needed to rigorously explore the causal relationships between collective gardening (and its intensity) and health status. Positive results from such studies would then make a compelling case for the use of community gardens as a tool to promote the health of urban dwellers. 


\section{ACKNOWLEDGEMENTS}

\section{Funding}

487 This research was part of doctoral thesis of M.T. co-funded by INRAE and the Surfood488 Foodscape project, the latter being publicly funded through ANR (the French National Research 489 Agency) under the "Investissements d'avenir" programme, reference ANR-10-LABX-001-01 490 Labex Agro, and coordinated by the Agropolis Foundation. This research was also supported 491 by the Olga Triballat Institute. The funders had no role in the design of the study or the 492 collection, analysis and interpretation of data, or in writing the manuscript.

\section{Competing interests}

495 The authors declare that they have no competing interests.

496

497

\section{Author contributions}

498 M.T and N.D. contributed to the design and methodology of the review. M.T. searched and 499 screened the literature and extracted the data. M.T and N.D. performed quality assessment. 500 M.T. collated the results and drafted the manuscript. All authors contributed to the critical review of the manuscript. 
1. WHO Regional Office for Europe. Urban Green Space Interventions and Health: A Review of Impacts and Effectiveness. Full Report. Copenhagen: Copenhagen : WHO Regional Office for Europe; 2017.

2. WHO Regional Office for Europe. Urban Green Spaces and Health - a Review of Evidence. Copengague: World Health Organization; 2016.

3. Schram-Bijkerk D, Otte P, Dirven L, Breure AM. Indicators to support healthy urban gardening in urban management. Sci Total Environ. 2018;621:863-871. doi:10.1016/J.SCITOTENV.2017.11.160

4. Pourias J, Duchemin E, Aubry C. Products from urban collective gardens: Food for thought or for consumption? Insights from Paris and Montreal. J Agric Food Syst Community Dev. 2015;5(2):1-25. doi:10.5304/jafscd.2015.052.005

5. Lawson LJ. City Bountiful : A Century of Community Gardening in America. Berkeley and Los Angeles, California: University of California Press; 2005.

6. Kurtz H. Differentiating multiple meanings of garden and community. Urban Geogr. 2001;22(7):656-670. doi:10.2747/0272-3638.22.7.656

7. Pourias J, Aubry C, Duchemin E. Is food a motivation for urban gardeners? Multifunctionality and the relative importance of the food function in urban collective gardens of Paris and Montreal. Agric Human Values. 2016;33(2):257-273. doi:10.1007/s10460-015-9606-y Leaves Publications; 3rd Revised edition edition; 1997. 
9. Archer JE. The Nineteenth-Century Allotment: Half an Acre and a Row. Econ Hist Rev. 1997;50(1):21-36. doi:10.1111/1468-0289.00043

10. Soga M, Gaston KJ, Yamaura Y. Gardening is beneficial for health: A meta-analysis. Prev Med Reports. 2017;5:92. doi:10.1016/J.PMEDR.2016.11.007

11. Wang D, MacMillan T. The Benefits of Gardening for Older Adults: A Systematic Review of the Literature. Act Adapt Aging. 2013;37(2):153-181. doi:10.1080/01924788.2013.784942

12. Ohly H, Gentry S, Wigglesworth R, Bethel A, Lovell R, Garside R. A systematic review of the health and well-being impacts of school gardening: synthesis of quantitative and qualitative evidence. BMC Public Health. 2016;16(1):286. doi:10.1186/s12889-016-2941-0

13. Savoie-Roskos MR, Wengreen H, Durward C. Increasing Fruit and Vegetable Intake among Children and Youth through Gardening-Based Interventions: A Systematic Review. J Acad Nutr Diet. 2017;117(2):240-250. doi:10.1016/j.jand.2016.10.014

14. Rochira A, Tedesco D, Ubiali A, Fantini MP, Gori D. School Gardening Activities Aimed at Obesity Prevention Improve Body Mass Index and Waist Circumference Parameters in School-Aged Children: A Systematic Review and Meta-Analysis. Child Obes. 2020;16(3):154-173. doi:10.1089/chi.2019.0253

15. Zhao Y, Liu Y, Wang Z. Effectiveness of horticultural therapy in people with dementia: A quantitative systematic review. J Clin Nurs. 2020;00:1-15. doi:10.1111/jocn.15204

16. Cipriani J, Benz A, Holmgren A, Kinter D, McGarry J, Rufino G. A Systematic Review of the Effects of Horticultural Therapy on Persons with Mental Health 
Conditions. Occup Ther Ment Heal. 2017;33(1):47-69.

doi:10.1080/0164212X.2016.1231602

17. Kunpeuk W, Spence W, Phulkerd S, Suphanchaimat R, Pitayarangsarit S. The impact of gardening on nutrition and physical health outcomes: a systematic review and metaanalysis. Health Promot Int. 2020;35(2):397-408. doi:10.1093/heapro/daz027

18. Draper C, Freedman D. Review and analysis of the benefits, purposes, and motivations associated with community gardening in the United States. J Community Pract. 2010;18(4):458-492. doi:10.1080/10705422.2010.519682

19. Guitart D, Pickering C, Byrne J. Past results and future directions in urban community gardens research. Urban For Urban Green. 2012;11:364-373. doi:10.1016/j.ufug.2012.06.007

20. Egli V, Oliver M, Tautolo E-S. The development of a model of community garden benefits to wellbeing. Prev Med Reports. 2016;3:348-352. doi:10.1016/J.PMEDR.2016.04.005

21. Garcia MT, Ribeiro SM, Germani ACCG, Bógus CM. The impact of urban gardens on adequate and healthy food: a systematic review. Public Health Nutr. 2018;21(2):416425. doi:10.1017/S1368980017002944

22. Audate PP, Fernandez MA, Cloutier G, Lebel A. Scoping review of the impacts of urban agriculture on the determinants of health. BMC Public Health. 2019;19(1):672. doi:10.1186/s12889-019-6885-z

23. Malberg Dyg P, Christensen S, Peterson CJ. Community gardens and wellbeing amongst vulnerable populations: a thematic review. Health Promot Int. 2019;35(4):790-803. doi:10.1093/heapro/daz067 
572 24. McCormack LA, Laska MN, Larson NI, Story M. Review of the Nutritional Implications of Farmers' Markets and Community Gardens: A Call for Evaluation and Research Efforts. J Am Diet Assoc. 2010;110(3):399-408. doi:10.1016/j.jada.2009.11.023

25. Machida D, Kushida O. The Influence of Food Production Experience on Dietary Knowledge, Awareness, Behaviors, and Health among Japanese: A Systematic Review. Int J Environ Res Public Health. 2020;17(3):924. doi:10.3390/ijerph17030924

26. Alaimo K, Beavers AW, Crawford C, Snyder EH, Litt JS. Amplifying health through community gardens: A framework for advancing multicomponent, behaviorally basedneighborhood interventions. Curr Environ Heal Reports. 2016;3(3):302-312. doi:10.1007/s40572-016-0105-0

27. Al-Delaimy WK, Webb M. Community Gardens as Environmental Health Interventions: Benefits Versus Potential Risks. Curr Environ Heal Reports. 2017;4(2):252-265. doi:10.1007/s40572-017-0133-4

28. WHO. Constitution of the World Health Organization. Geneva: World Health Organization; 1948.

29. Liberati A, Altman DG, Tetzlaff J, et al. The PRISMA statement for reporting systematic reviews and meta-analyses of studies that evaluate healthcare interventions: explanation and elaboration. BMJ. 2009;339:b2700. doi:10.1136/bmj.b2700

30. Hall SA, Kaufman JS, Ricketts TC. Defining urban and rural areas in U.S. epidemiologic studies. J Urban Heal. 2006;83(2):162-175. doi:10.1007/s11524-0059016-3

31. Booth JM, Chapman D, Ohmer ML, Wei K. Examining the Relationship Between 
Level of Participation in Community Gardens and their Multiple Functions. $J$ Community Pract. 2018;26(1):5-22. doi:10.1080/10705422.2017.1413024

32. Van den Berg AE, Van Winsum-Westra M, De Vries S, Van Dillen SME. Allotment gardening and health: a comparative survey among allotment gardeners and their neighbors without an allotment. Environ Heal. 2010;9(1):74. doi:10.1186/1476-069X$9-74$

33. Alaimo K, Reischl TM, Allen JO. Community gardening, neighborhood meetings, and social capital. J Community Psychol. 2010;38(4):497-514. doi:10.1002/jcop.20378

34. Alaimo K, Packnett E, Miles RA, Kruger DJ. Fruit and vegetable intake among urban community gardeners. J Nutr Educ Behav. 2008;40(2):94-101. doi:10.1016/j.jneb.2006.12.003

35. Algert SJ, Diekmann L, Renvall M, Gray L. Community and home gardens increase vegetable intake and food security of residents in San Jose, California. Calif Agric. 2016;70(2):77-82. doi:10.3733/ca.v070n02p77

36. Comstock N, Miriam Dickinson L, Marshall JA, et al. Neighborhood attachment and its correlates: Exploring neighborhood conditions, collective efficacy, and gardening. $J$ Environ Psychol. 2010;30(4):435-442. doi:10.1016/J.JENVP.2010.05.001

37. Hawkins JL, Thirlaway KJ, Backx K, Clayton DA. Allotment Gardening and Other Leisure Activities for Stress Reduction and Healthy Aging. Horttechnology. October 2011:577-585. doi:10.21273/HORTTECH.21.5.577

38. Litt JS, Soobader M-J, Turbin MS, Hale JW, Buchenau M, Marshall JA. The Influence of Social Involvement, Neighborhood Aesthetics, and Community Garden Participation on Fruit and Vegetable Consumption. Am J Public Health. 2011;101(8):1466. 
doi:10.2105/ajph.2010.300111

619

620

621

622

623

624

625

626

627

628

629

630

631

632

633

634

635

636

637

638

639

640

39. Litt JS, Lambert JR, Glueck DH. Gardening and age-related weight gain: Results from a cross-sectional survey of Denver residents. Prev Med Reports. 2017;8:221-225. doi:10.1016/j.pmedr.2017.10.018

40. Martin P, Consalès J-N, Scheromm P, Marchand P, Ghestem F, Darmon N. Community gardening in poor neighborhoods in France: A way to re-think food practices? Appetite. 2017;116:589-598. doi:10.1016/j.appet.2017.05.023

41. Mourão I, Moreira MC, Almeida TC, Brito LM. Perceived changes in well-being and happiness with gardening in urban organic allotments in Portugal. Int J Sustain Dev World Ecol. 2019;26(1):79-89. doi:10.1080/13504509.2018.1469550

42. Soga M, Cox D, Yamaura Y, et al. Health Benefits of Urban Allotment Gardening: Improved Physical and Psychological Well-Being and Social Integration. Int J Environ Res Public Health. 2017;14(1):71. doi:10.3390/ijerph14010071

43. Van Den Berg AE, Custers MHG. Gardening promotes neuroendocrine and affective restoration from stress. J Health Psychol. 2011;16(1):3-11. doi:10.1177/1359105310365577

44. Young C, Hofmann M, Frey D, Moretti M, Bauer N. Psychological restoration in urban gardens related to garden type, biodiversity and garden-related stress. Landsc Urban Plan. 2020;198:103777. doi:10.3929/ETHZ-B-000405672

45. Zick CD, Smith KR, Kowaleski-Jones L, Uno C, Merrill BJ. Harvesting More Than Vegetables: The Potential Weight Control Benefits of Community Gardening. Am J Public Health. 2013;103(6):1110-1115. doi:10.2105/AJPH.2012.301009

46. Armijo-Olivo S, Stiles CR, Hagen NA, Biondo PD, Cummings GG. Assessment of 
study quality for systematic reviews: A comparison of the Cochrane Collaboration Risk of Bias Tool and the Effective Public Health Practice Project Quality Assessment Tool: Methodological research. J Eval Clin Pract. 2012;18(1):12-18. doi:10.1111/j.13652753.2010.01516.x

47. Algert SJ, Baameur A, Renvall MJ. Vegetable Output and Cost Savings of Community Gardens in San Jose, California. J Acad Nutr Diet. 2014;114(7):1072-1076. doi:10.1016/j.jand.2014.02.030

48. Glass TA, Goodman SN, Hernán MA, Samet JM. Causal Inference in Public Health. Annu Rev Public Health. 2013;34(1):61-75. doi:10.1146/annurev-publhealth-031811124606

49. Coughlin SS. Recall bias in epidemiologic studies. J Clin Epidemiol. 1990;43(1):87-91. doi:10.1016/0895-4356(90)90060-3

50. Kristal AR, Vizenor NC, Patterson RE, Neuhouser ML, Shattuck AL, McLerran D. Precision and bias of food frequency-based measures of fruit and vegetable intakes. Cancer Epidemiol Biomarkers Prev. 2000;9(9):939-944.

51. Kim DJ, Holowaty EJ. Brief, validated survey instruments for the measurement of fruit and vegetable intakes in adults: a review. Prev Med (Baltim). 2003;36(4):440-447. doi:10.1016/S0091-7435(02)00040-3

52. Prince SA, Adamo KB, Hamel M, Hardt J, Connor Gorber S, Tremblay M. A comparison of direct versus self-report measures for assessing physical activity in adults: a systematic review. Int J Behav Nutr Phys Act. 2008;5(1):56. doi:10.1186/1479-5868-5-56

53. Sylvia LG, Bernstein EE, Hubbard JL, Keating L, Anderson EJ. Practical guide to 
measuring physical activity. J Acad Nutr Diet. 2014;114(2):199-208. doi:10.1016/j.jand.2013.09.018

54. Hills AP, Mokhtar N, Byrne NM. Assessment of physical activity and energy expenditure: an overview of objective measures. Front Nutr. 2014;1(5):1-16. doi:10.3389/fnut.2014.00005

55. Dowd KP, Szeklicki R, Minetto MA, et al. A systematic literature review of reviews on techniques for physical activity measurement in adults: a DEDIPAC study. Int J Behav Nutr Phys Act. 2018;15(1):15. doi:10.1186/s12966-017-0636-2

56. Demark-Wahnefried W, Cases MG, Cantor AB, et al. Pilot Randomized Controlled Trial of a Home Vegetable Gardening Intervention among Older Cancer Survivors Shows Feasibility, Satisfaction, and Promise in Improving Vegetable and Fruit Consumption, Reassurance of Worth, and the Trajectory of Central Adiposity. J Acad Nutr Diet. 2018;118(4):689-704. doi:10.1016/j.jand.2017.11.001

57. Bail JR, Frugé AD, Cases MG, et al. A home-based mentored vegetable gardening intervention demonstrates feasibility and improvcements in physical activity and performance among breast cancer survivors. Cancer. 2018;124(16):3427-3435. doi:10.1002/cncr.31559

58. Tharrey M, Sachs A, Perignon M, et al. Improving lifestyles sustainability through community gardening: results and lessons learnt from the JArDinS quasi-experimental study. BMC Public Health. 2020;20(1):1798. doi:10.1186/s12889-020-09836-6

59. Litt JS, Alaimo K, Buchenau M, et al. Rationale and design for the community activation for prevention study (CAPs): A randomized controlled trial of community gardening. Contemp Clin Trials. 2018;68:72-78. doi:10.1016/J.CCT.2018.03.005 
60. Gordon-Larsen P, Nelson MC, Page P, Popkin BM. Inequality in the built environment underlies key health disparities in physical activity and obesity. Pediatrics. 2006;117(2):417-424. doi:10.1542/peds.2005-0058

61. Morland K, Diez Roux A V., Wing S. Supermarkets, other food stores, and obesity: The Atherosclerosis Risk in Communities Study. Am J Prev Med. 2006;30(4):333-339. doi:10.1016/j.amepre.2005.11.003

62. Kirkpatrick SI, Tarasuk V. Food insecurity and participation in community food programs among low-income Toronto families. Can J Public Heal. 2009;100(2):135139. doi:10.1007/bf03405523

63. Loopstra R, Tarasuk V. Perspectives on community gardens, community kitchens and the good food box program in a community-based sample of low-income families. Can J Public Heal. 2013;104(1):e55-e59. doi:10.1007/bf03405655

64. Brown VM, Allen AC, Dwozan M, Mercer I, Warren K. Indoor gardening older adults: effects on socialization, activities of daily living, and loneliness. J Gerontol Nurs. 2004;30(10):34-42. doi:10.3928/0098-9134-20041001-10

65. Han AR, Park SA, Ahn BE. Reduced stress and improved physical functional ability in elderly with mental health problems following a horticultural therapy program. Complement Ther Med. 2018;38:19-23. doi:10.1016/j.ctim.2018.03.011

66. Tse MMY. Therapeutic effects of an indoor gardening programme for older people living in nursing homes. J Clin Nurs. 2010;19(7-8):949-958. doi:10.1111/j.13652702.2009.02803.x

67. Park S-A, Lee A-Y, Son K-C, Lee W-L, Kim D-S. Gardening Intervention for Physical and Psychological Health Benefits in Elderly Women at Community Centers. 
Horttechnology. 2016;26(4):474-483.

711

712

713

714

715

716

717

718

719

720

721

722

723

724

725

726

727

728

729

730

731

732

68. Ng KST, Sia A, Ng MKW, et al. Effects of horticultural therapy on asian older adults: A randomized controlled trial. Int J Environ Res Public Health. 2018;15(8):1705. doi:10.3390/ijerph15081705

69. Park S-A, Lee A-Y, Park H-G, Son K-C, Kim D-S, Lee W-L. Gardening Intervention as a Low- to Moderate-Intensity Physical Activity for Improving Blood Lipid Profiles, Blood Pressure, Inflammation, and Oxidative Stress in Women over the Age of 70: A Pilot Study. HortScience. 2017;52(1):200-205. doi:10.21273/HORTSCI11232-16

70. Frumkin H, Bratman GN, Breslow SJ, et al. Nature Contact and Human Health: A Research Agenda. Environ Health Perspect. 2017;125(7):075001(1-18). doi:10.1289/EHP1663

71. Litt JS, Schmiege SJ, Hale JW, Buchenau M, Sancar F. Exploring ecological, emotional and social levers of self-rated health for urban gardeners and non-gardeners: A path analysis. Soc Sci Med.2015;144:1-8. doi:10.1016/J.SOCSCIMED.2015.09.004

72. Machida D. Relationship between Community or Home Gardening and Health of the Elderly: A Web-Based Cross-Sectional Survey in Japan. Int J Environ Res Public Health. 2019;16(8):1389. doi:10.3390/ijerph16081389

73. Wood CJ, Pretty J, Griffin M. A case-control study of the health and well-being benefits of allotment gardening. J Public Health (Bangkok). 2016;38(3):e336-e344. doi:10.1093/pubmed/fdv146

74. Eigenbrod C, Gruda N. Urban vegetable for food security in cities. A review. Agron Sustain Dev. 2015;35(2):483-498. doi:10.1007/s13593-014-0273-y

75. Thomas BH, Ciliska D, Dobbins M, Micucci S. A process for systematically reviewing 
the literature: Providing the research evidence for public health nursing interventions. 475X.2004.04006.x

736

737

738

739

740

741

742

76. Jackson N, Waters E. Criteria for the systematic review of health promotion and public health interventions. Health Promot Int. 2005;20(4):367-374. doi:10.1093/heapro/dai022

77. Deeks JJ, Dinnes J, D’Amico R, et al. Evaluating non-randomised intervention studies. Health Technol Assess (Rockv). 2003;7(27):1-173. doi:10.3310/hta7270 


\section{TABLE LEGEND}

Table 1. PICOS criteria for inclusion and exclusion of studies

Table 2. Descriptive characteristics of included studies on health benefits of participation in an urban collective garden ${ }^{\alpha}$

Table 3. EPHPP Quality Assessment of Included Studies

\section{FIGURE LEGEND}

Figure 1. PRISMA flow diagram 
Table 1. PICOS criteria for inclusion and exclusion of studies

\begin{tabular}{|c|c|c|}
\hline Parameter & Inclusion criteria & Exclusion criteria \\
\hline Population & $\begin{array}{l}\text { Free-living adults (i.e., non-institutionalized) aged } \geq 18 \\
\text { years living in urban area of western and other high- } \\
\text { income countries }\end{array}$ & $\begin{array}{l}\text { Population aged }<18 \text { years } \\
\text { Institutionalized settings (hospital, nursing home, health center, prison } \\
\text { or refugee camp) } \\
\text { Rural areas } \\
\text { Low-income countries }\end{array}$ \\
\hline Intervention & Participation in a collective garden & $\begin{array}{l}\text { Gardening without further details } \\
\text { Home gardening } \\
\text { Ornamental gardening } \\
\text { Therapeutic gardening } \\
\text { Other forms of gardening not undertaken in a collective garden }\end{array}$ \\
\hline Comparison & Not applicable & Not applicable \\
\hline Outcomes & $\begin{array}{l}\text { Any physical, mental, or social quantitative health } \\
\text { outcomes }\end{array}$ & $\begin{array}{l}\text { Qualitative data } \\
\text { Non-health-related outcomes }\end{array}$ \\
\hline Study design & $\begin{array}{l}\text { Original research studies of any interventional or } \\
\text { observational design }\end{array}$ & $\begin{array}{l}\text { Literature reviews, case reports, theses and dissertations, letters, book } \\
\text { chapters, authors' comments, and other grey literature }\end{array}$ \\
\hline
\end{tabular}


Table 2. Descriptive characteristics of included studies on health benefits of participation in an urban collective garden

\begin{tabular}{|c|c|c|c|c|c|c|c|}
\hline Reference & Setting & Study design & $\begin{array}{l}\text { Population, } \\
\text { Study groups (G1, G2...) }\end{array}$ & $\begin{array}{l}\text { Mean age } \\
\text { (year); } \\
\% \text { women }\end{array}$ & $\begin{array}{l}\text { Length and } \\
\text { frequency of } \\
\text { gardening }\end{array}$ & $\begin{array}{c}\text { Data collected } \\
(\text { Assessment tools) }\end{array}$ & Main results ${ }^{a}$ \\
\hline $\begin{array}{l}\text { Alaimo et } \\
\text { al. }(2008)^{34}\end{array}$ & $\begin{array}{l}\text { Flint, MI, } \\
\text { USA }\end{array}$ & $\begin{array}{l}\text { Cross-sectional, } \\
\text { random sample } \\
\text { representative of } \\
\text { the general } \\
\text { population, } \\
\text { comparison } \\
\text { group }\end{array}$ & $\begin{array}{l}\mathrm{n}=766 \text { households with: } \\
\text { G1: at least } 1 \text { community } \\
\text { garden member }(\mathrm{n}=116) \\
\mathrm{G} 2: \text { no community garden } \\
\text { members }(\mathrm{n}=650)\end{array}$ & $43.8 ; 51.9$ & NS & $\begin{array}{l}\text { Dietary behaviors: } \\
\text { Fruit and vegetable intake }(B R F S S)\end{array}$ & $\begin{array}{l}\text { Participants in G1 consumed fruits } \\
\text { and vegetables } 1.4 \text { more times per } \\
\text { day than those in } G 2 \text {, and were } 3.5 \\
\text { times more likely to consume fruits } \\
\text { and vegetables } \geq 5 \text { times daily. }\end{array}$ \\
\hline $\begin{array}{l}\text { Alaimo et } \\
\text { al. }(2010)^{33}\end{array}$ & $\begin{array}{l}\text { Flint, MI, } \\
\text { USA }\end{array}$ & $\begin{array}{l}\text { Cross-sectional, } \\
\text { random sample } \\
\text { representative of } \\
\text { the general } \\
\text { population, } \\
\text { comparison } \\
\text { groups }\end{array}$ & $\begin{array}{l}\mathrm{n}=1916 \text { households } \\
\text { participating in: } \\
\mathrm{G} 1 \text { : community garden or } \\
\text { beautification project }(\mathrm{n}= \\
271) \\
\text { G2: neighborhood association } \\
\text { meetings } \\
(\mathrm{n}=129) \\
\text { G3: both } \mathrm{G} 1 \text { \& G2 }(\mathrm{n}=292) \\
\mathrm{G} 4: \text { neither } \mathrm{G} 1 \text { nor } \mathrm{G} 2 \\
(\mathrm{n}=1224)\end{array}$ & $\begin{array}{l}\text { G1: } 40.7 ; 54.3 \\
\text { G2: } 45.9 ; 47.7 \\
\text { G3: } 43.8 ; 47.7 \\
\text { G4: } 45.5 ; 56.7\end{array}$ & NS & $\begin{array}{l}\text { Social health: } \\
\text { - Bonding social capital (12-item } \\
Q \text { ) } \\
\text { - Linking social capital (3-item } Q) \\
\text { - Neighborhood norms and values } \\
(14 \text {-item } Q)\end{array}$ & $\begin{array}{l}\text { Households participation in G1, G2 } \\
\text { or G3 was associated with better } \\
\text { social outcomes when compared to } \\
\text { G4. Associations with participation } \\
\text { in group G3 were higher than for } \\
\text { participation in groups G1 or G2. }\end{array}$ \\
\hline $\begin{array}{l}\text { Algert et al. } \\
(2016)^{35}\end{array}$ & $\begin{array}{l}\text { San Jose, } \\
\text { CA, USA }\end{array}$ & $\begin{array}{l}\text { Cross-sectional, } \\
\text { convenience } \\
\text { sample, } \\
\text { comparison } \\
\text { group }\end{array}$ & $\begin{array}{l}\mathrm{n}=135 \text { adults, low-income } \\
\text { population: } \\
\text { G1: home gardeners }(\mathrm{n}=50) \\
\mathrm{G} 2: \text { community gardeners }(\mathrm{n} \\
=85)\end{array}$ & $\begin{array}{l}\text { G1: } 49 ; 84 \\
\text { G2: } 58 ; 50\end{array}$ & $\begin{array}{l}\text { Length of time: } \\
\text { G1: } 48 \% \text { with }<2 \\
\text { years of experience } \\
\text { G2: } 33 \% \text { with }<2 \\
\text { years of experience }\end{array}$ & $\begin{array}{l}\text { Dietary behaviors: } \\
\begin{array}{l}\text { Vegetable intake (food behaviour } \\
\text { checklist from the EFNEP }+1- \\
\text { item } Q)\end{array} \\
\text { Anthropometric outcomes: } \\
\begin{array}{l}\text { BMI (self-reported height and } \\
\text { weight) }\end{array}\end{array}$ & $\begin{array}{l}\text { Participants reported having doubled } \\
\text { their vegetable intake to a level } \\
\text { meeting the } 2.5 \text { daily servings } \\
\text { recommended by the US Dietary } \\
\text { Guidelines ( }+1.9 \text { cups/day.person for } \\
\text { G1 vs }+2.0 \text { cups/day.person for G2). } \\
\text { No difference in BMI between the } \\
\text { two groups. }\end{array}$ \\
\hline
\end{tabular}




\begin{tabular}{|c|c|c|c|c|c|c|c|}
\hline $\begin{array}{l}\text { Booth et al., } \\
(2018)^{31}\end{array}$ & $\begin{array}{c}\text { USA } \\
\text { Urban areas }\end{array}$ & $\begin{array}{l}\text { Cross-sectional, } \\
\text { convenience } \\
\text { sample, } \\
\text { comparison } \\
\text { group }\end{array}$ & $\begin{array}{l}\mathrm{n}=115 \text { adults, low-income } \\
\text { population: } \\
\text { G1: regular community } \\
\text { gardeners }(\mathrm{n}=16) \\
\mathrm{G} 2 \text { : occasional community } \\
\text { gardeners }(\mathrm{n}=43) \\
\text { G3: nongardeners }(\mathrm{n}=56)\end{array}$ & $42.1 ; 57.8$ & $\begin{array}{l}\text { Participation: } \\
\text { - regular gardeners : } \\
>12 \text { times/year } \\
\text { - occasional } \\
\text { gardeners : } \leq 12 \\
\text { times/year }\end{array}$ & $\begin{array}{l}\text { Dietary behaviors: } \\
\text { Frequency (per week) of fruit, } \\
\text { vegetables, soda, and fast-food } \\
\text { intake (4-item } Q \text { ) } \\
\text { Physical activity: } \\
\text { Frequency (per week) of moderate } \\
\text { and vigorous PA (2-item } Q \text { ) } \\
\text { Others' physical health outcomes: } \\
\text { Self-perceived general health } \\
\text { (1-item } Q \text { ) } \\
\text { Mental health: } \\
\text { - Individual empowerment (2-item } \\
Q \text { ) } \\
\text { - Psychological well-being (WHO- } \\
\text { 5) } \\
\text { - Psychological distress } \\
\text { (K-6 Distress scale) } \\
\text { - Life satisfaction (10-item } Q) \\
\text { Social health: } \\
\text { - Sense of community (13-item } Q \text { ) } \\
\text { - Community empowerment }(4- \\
\text { item } Q \text { ) } \\
\text { - Organizational empowerment (5- } \\
\text { item } Q \text { ) }\end{array}$ & $\begin{array}{l}\text { Participants in G1 \& G2 reported } \\
\text { greater psychological well-being and } \\
\text { community empowerment than did } \\
\text { G3. } \\
\text { Participants in G1 reported higher } \\
\text { organizational empowerment than } \\
\text { G2 \& G3 participants and higher } \\
\text { sense of community than G2 } \\
\text { participants. } \\
\text { Participants in G2 report consuming } \\
\text { vegetables } 1.3 \text { more times per week } \\
\text { and a lower psychological distress } \\
\text { score than G3 participants. } \\
\text { No difference in intake of fruits, } \\
\text { soda and fast-food, PA and self- } \\
\text { perceived general health, individual } \\
\text { empowerment and life satisfaction } \\
\text { between groups. }\end{array}$ \\
\hline $\begin{array}{l}\text { Comstock } \\
\text { et al. } \\
(2010)^{36}\end{array}$ & $\begin{array}{c}\text { Denver, } \\
\text { CO, USA }\end{array}$ & $\begin{array}{l}\text { Cross-sectional, } \\
\text { random } \\
\text { multiframe } \\
\text { sample, } \\
\text { comparison } \\
\text { groups }\end{array}$ & $\begin{array}{l}\mathrm{n}=410 \text { adults: } \\
\text { G1: community gardeners }(\mathrm{n} \\
=31) \\
\text { G2: home gardeners }(\mathrm{n}= \\
\text { 197) } \\
\text { G3: nongardeners }(\mathrm{n}=182)\end{array}$ & $\begin{array}{l}\text { median age: } 45 \\
\text { (range 18-94); } \\
\text { NA }\end{array}$ & NS & $\begin{array}{l}\text { Social health: } \\
\text { Individual neighborhood } \\
\text { attachment (6-item } Q \text { ) }\end{array}$ & $\begin{array}{l}\text { Participants in G1 \& G2 reported } \\
\text { higher levels of neighborhood } \\
\text { attachment than G3 participants. }\end{array}$ \\
\hline
\end{tabular}




\begin{tabular}{|c|c|c|c|c|c|c|c|}
\hline $\begin{array}{l}\text { Hawkins et } \\
\text { al. }(2011)^{37}\end{array}$ & Cardiff, UK & $\begin{array}{l}\text { Cross-sectional, } \\
\text { convenience } \\
\text { sample, } \\
\text { comparison } \\
\text { groups }\end{array}$ & $\begin{array}{l}\mathrm{n}=94 \text { adults }>50 \text { years: } \\
\text { G1: allotment gardeners }(\mathrm{n}= \\
\text { 25) } \\
\text { G2: home gardeners }(\mathrm{n}=21) \\
\text { G3: members of outdoor- } \\
\text { walking groups }(\mathrm{n}=25) \\
\text { G4: members of indoor- } \\
\text { exercising groups }(\mathrm{n}=23)\end{array}$ & $\begin{array}{l}\text { G1: } 65.7 ; 8 \\
\text { G2: } 69.5 ; 19 \\
\text { G3: } 62.4 ; 17 \\
\text { G4: } 72.9 ; 20\end{array}$ & NS & $\begin{array}{l}\text { Anthropometric outcomes: } \\
\text { BMI (objective measures) } \\
\text { Physical activity: } \\
\text { - Frequency and duration of } \\
\text { moderate and vigorous(min/week) } \\
\text { (IPAQ short-form) } \\
\text { - Sitting time (min/week) (IPAQ } \\
\text { short-form) } \\
\text { Others' physical health outcomes: } \\
\text { - Blood pressure (physiological } \\
\text { measure) } \\
\text { - Lung function (physiological } \\
\text { measure) } \\
\text { - General physical health (Quality } \\
\text { of Life } Q \text { (SF-36v2)) } \\
\text { Mental health: } \\
\text { - Perceived stress (perceived stress } \\
\text { scale) } \\
\text { - General mental health (Quality of } \\
\text { Life } Q \text { (SF-36v2)) } \\
\text { Social health: } \\
\text { Perceived social support (social } \\
\text { provisions scale) }\end{array}$ & $\begin{array}{l}\text { Participants in G1 reported lower } \\
\text { perceived stress than G4 participants } \\
(9.8 \pm 5.8 \text { vs } 15.8 \pm 6.1) \text {. No } \\
\text { difference for other outcomes } \\
\text { between groups. }\end{array}$ \\
\hline $\begin{array}{l}\text { Litt et al. } \\
(2011)^{38}\end{array}$ & $\begin{array}{l}\text { Denver, } \\
\text { CO, USA }\end{array}$ & $\begin{array}{l}\text { Cross-sectional, } \\
\text { random } \\
\text { multiframe } \\
\text { sample, } \\
\text { comparison } \\
\text { groups }\end{array}$ & $\begin{array}{l}\mathrm{n}=436 \text { adults: } \\
\text { G1: community gardeners }(\mathrm{n} \\
=41) \\
\text { G2: home gardeners }(\mathrm{n}= \\
\text { 208) } \\
\text { G3: NG }(\mathrm{n}=187)\end{array}$ & $46 ; 68$ & NS & $\begin{array}{l}\text { Dietary behaviors: } \\
\text { Fruit and vegetable intake (BRFSS) }\end{array}$ & $\begin{array}{l}\text { Participants in G1 reported higher } \\
\text { frequency of fruits and vegetables } \\
\text { intake than those in G2 \& G3 (5.0, } \\
4.3 \text { and } 3.9 \text { times/day respectively) }\end{array}$ \\
\hline $\begin{array}{l}\text { Litt et al. } \\
(2017)^{39}\end{array}$ & $\begin{array}{l}\text { Denver, } \\
\text { CO, USA }\end{array}$ & $\begin{array}{l}\text { Cross-sectional, } \\
\text { random } \\
\text { multiframe } \\
\text { sample, } \\
\text { comparison } \\
\text { groups }\end{array}$ & $\begin{array}{l}\mathrm{n}=469 \text { adults: } \\
\text { G1: community gardeners }(\mathrm{n} \\
=63) \\
\text { G2: home gardeners }(\mathrm{n}= \\
\text { 215) } \\
\text { G3: NG }(\mathrm{n}=191)\end{array}$ & $\begin{array}{l}46.1 \text { y } 67.4 \\
\%\end{array}$ & NS & $\begin{array}{l}\text { Anthropometric outcomes: } \\
\begin{array}{l}\text { BMI (self-report height and } \\
\text { weight) }\end{array}\end{array}$ & $\begin{array}{l}\text { Participants in G1 \& G2 had on } \\
\text { average a lower BMI than those in } \\
\text { G3. In unadjusted model, BMI } \\
\text { increased by } 0.03\left(\mathrm{~kg} / \mathrm{m}^{2}\right) \text { for every } \\
\text { year of age increase only for G3 }\end{array}$ \\
\hline
\end{tabular}




\begin{tabular}{|c|c|c|c|c|c|c|c|}
\hline & & & & & & & $\begin{array}{l}\text { participants, but the association } \\
\text { disappeared in adjusted model. }\end{array}$ \\
\hline $\begin{array}{l}\text { Martin et al. } \\
(2017)^{40}\end{array}$ & $\begin{array}{l}\text { Marseille, } \\
\text { France }\end{array}$ & $\begin{array}{l}\text { Cross-sectional, } \\
\text { convenience } \\
\text { sample, } \\
\text { comparison } \\
\text { group }\end{array}$ & $\begin{array}{l}\mathrm{n}=87 \text { adults, low-income } \\
\text { population: } \\
\text { G1: community gardeners ( } \\
=21) \\
\text { G2: nongardeners }(\mathrm{n}=65) \\
\end{array}$ & $\begin{array}{l}\text { G1: } 52.0 ; 100 \\
\text { G2: NS; } 100\end{array}$ & $\begin{array}{l}\text { Mean garden } \\
\text { occupancy time: } 21 \\
\text { months (range: } 0-48 \\
\text { months) }\end{array}$ & $\begin{array}{l}\text { Dietary behaviors: } \\
\text { Monthly household food supplies } \\
\text { including purchases and garden } \\
\text { production (food supply diary) }\end{array}$ & $\begin{array}{l}\text { Participants in G1 had, on average, } \\
\text { higher fruit and vegetable food } \\
\text { supply than G2 participants ( }+158 \\
\text { g/day.person). No difference for } \\
\text { other food groups between groups. }\end{array}$ \\
\hline $\begin{array}{l}\text { Mourão et } \\
\text { al. }(2018)^{41}\end{array}$ & $\begin{array}{l}\text { Vila Nova } \\
\text { de } \\
\text { Famalicão, } \\
\text { Portugal }\end{array}$ & $\begin{array}{l}\text { Cross-sectional, } \\
\text { convenience } \\
\text { sample }\end{array}$ & $\mathrm{n}=65$ allotment gardeners & $\begin{array}{l}\cdot 25-45 \text { years } \\
(37 \%) \\
\cdot 46-65 \text { years } \\
(48 \%) \\
\cdot>65 \text { years }(15 \\
\%) \\
; 43.1\end{array}$ & $\begin{array}{l}\text { - Gardening every } \\
\text { day }(41.5 \%) \\
\bullet \text { Gardening several } \\
\text { days/week }(\mathrm{n}=47.7 \\
\%) \\
\text { - Gardening once a } \\
\text { week }(10.8 \%)\end{array}$ & $\begin{array}{l}\text { Mental health: } \\
\text { Subjective happiness (subjective } \\
\text { happiness scale) }\end{array}$ & $\begin{array}{l}\text { Participants who visited the garden } \\
\text { more frequently considered } \\
\text { themselves happier in comparison } \\
\text { with peers. }\end{array}$ \\
\hline $\begin{array}{l}\text { Soga et al. } \\
(2017)^{42}\end{array}$ & $\begin{array}{l}\text { Tokyo, } \\
\text { Japan }\end{array}$ & $\begin{array}{l}\text { Cross-sectional, } \\
\text { convenience } \\
\text { sample, } \\
\text { comparison } \\
\text { group }\end{array}$ & $\begin{array}{l}n=332 \text { adults: } \\
\text { G1: allotment gardeners }(n= \\
\text { 165) } \\
\text { G2: nongardeners }(n=167)\end{array}$ & $\begin{array}{l}\text { G1: } 61.9 ; 31.9 \\
\text { G2: } 61.0 ; 58.2\end{array}$ & $\begin{array}{l}\text { Mean number of } \\
\text { visits: } 15.7 \pm 10.9 \\
\text { times/month } \\
\text { Mean duration of } \\
\text { each visit: } 80.0 \pm \\
64.9 \text { min } \\
\text { Total mean duration } \\
\text { of all visits: } 21.0 \pm \\
25.7 \text { h/month }\end{array}$ & $\begin{array}{l}\text { Anthropometric outcomes: } \\
\text { BMI (self-reported height and } \\
\text { weight) } \\
\text { Others' physical health outcomes: } \\
\text { - Self-perceived general health (1- } \\
\text { item Q) } \\
\text { - Subjective health complaints (10- } \\
\text { item symptom checklist) } \\
\text { Mental health: } \\
\text { Psychological distress/mood } \\
\text { disturbance (General Health } Q) \\
\text { Social health: } \\
\text { Social cohesion (social Cohesion } \\
\text { and Trust Scale) }\end{array}$ & $\begin{array}{l}\text { Participants in G1 reported better } \\
\text { perceived general health and social } \\
\text { cohesion, and less subjective health } \\
\text { complaints and psychological } \\
\text { distress than G2 participants. No } \\
\text { difference in BMI between groups. }\end{array}$ \\
\hline $\begin{array}{l}\text { Van den } \\
\text { Berg et al. } \\
(2010)^{32}\end{array}$ & $\begin{array}{l}\text { Netherlands } \\
\text { Urban }(65 \\
\%) \\
\text { Peri-urban } \\
\quad(31 \%) \\
\text { Rural }(4 \%)\end{array}$ & $\begin{array}{l}\text { Cross-sectional, } \\
\text { convenience } \\
\text { sample, } \\
\text { comparison } \\
\text { group }\end{array}$ & $\begin{array}{l}\mathrm{n}=184 \text { adults: } \\
\mathrm{G} 1: \text { allotment gardeners } \geq 62 \\
\text { years }(\mathrm{n}=70) \\
\text { G2: allotment gardeners }<62 \\
\text { years }(\mathrm{n}=51)\end{array}$ & $\begin{array}{l}\text { G1: } 61.5 ; 47 \\
\text { G2: } 55.9 ; 59\end{array}$ & $\begin{array}{l}\text { Length of gardening: } \\
\text { - G1: 11-20 years } \\
\text { - G2: 6-10 years } \\
\text { Mean time spent on } \\
\text { gardening and }\end{array}$ & $\begin{array}{l}\text { Physical activity: } \\
\text { Frequency of PA in } \\
\text { summer and winter (2-item from } \\
\text { the SQUASH Q) } \\
\text { Others' physical health outcomes: }\end{array}$ & $\begin{array}{l}\text { Participants in G1 and G2 reported } \\
\text { more frequency of PA during } \\
\text { summer than G3 and G4 ( } 5.8 \pm 1.53 \\
\text { vs } 4.9 \pm 2.15 \text { days/week). Compared } \\
\text { to G3, participants in G1 reported } \\
\text { less physical constraints }(1.27 \pm 0.04\end{array}$ \\
\hline
\end{tabular}




\begin{tabular}{|c|c|c|c|c|c|c|c|}
\hline & & & $\begin{array}{l}\text { G3: nongardener neighbors } \\
\geq 62 \text { years }(\mathrm{n}=21) \\
\text { G4: nongardener neighbors } \\
<62 \text { years }(\mathrm{n}=42)\end{array}$ & & $\begin{array}{l}\text { maintenance } \\
\text { activities in the } \\
\text { garden: } \\
\text { - G1: } 66 \% \\
\text { - G2: } 56 \%\end{array}$ & 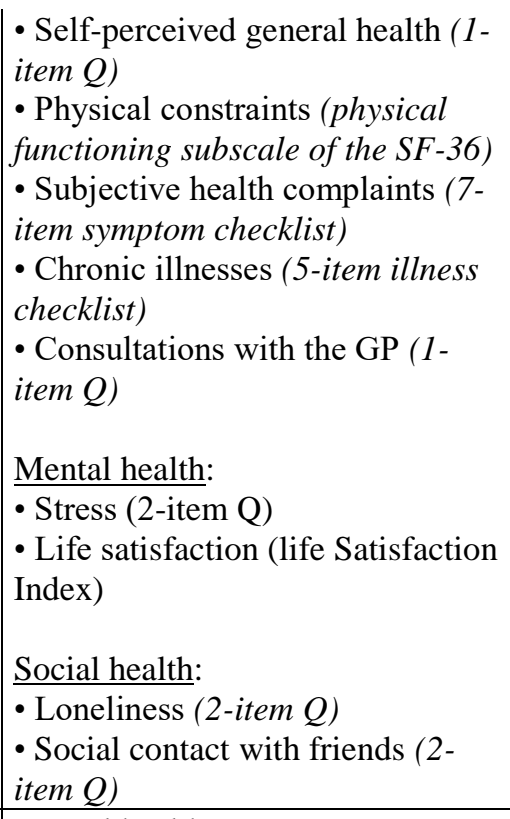 & $\begin{array}{l}\text { vs } 1.53 \pm 0.07) \text {, subjective health } \\
\text { complaints }(2.04 \pm 0.26 \text { vs } 3.83 \pm \\
0.45) \text {, consultations with their GP } \\
(0.52 \pm 0.13 \text { vs } 1.14 \pm 0.23) \text { and } \\
\text { loneliness }(0.28 \pm 0.09 \text { vs } 0.8 \pm \\
0.16) \text {, as well as more life } \\
\text { satisfaction }(2.29 \pm 0.06 \text { vs } 1.96 \pm \\
0.09) \text {. Participants in G1 also } \\
\text { reported less stress ( } 2.05 \pm 1.2 \text { vs } \\
3.20 \pm 0.14) \text { and more contact with } \\
\text { friends }(8.07 \pm 0.38 \text { vs } 6.14 \pm 0.43) \\
\text { than G2 participants, whereas there } \\
\text { were no difference between G2 and } \\
\text { G4 participants. No difference in } \\
\text { perceived general health and chronic } \\
\text { illnesses between groups. }\end{array}$ \\
\hline $\begin{array}{l}\text { Van den } \\
\text { Berg et al. } \\
(2011)^{43}\end{array}$ & $\begin{array}{l}\text { Amsterdam, } \\
\text { Netherlands }\end{array}$ & $\begin{array}{l}\text { Randomized } \\
\text { control trial }\end{array}$ & $\begin{array}{l}\mathrm{n}=30 \text { allotment gardeners. } \\
\text { After performing a stressful } \\
\text { task, participants were } \\
\text { randomly assigned to } 30 \text { min } \\
\text { of: } \\
\text { G1: outdoor gardening } \\
\text { activities }(\mathrm{n}=14) \\
\mathrm{G} 2 \text { : indoor reading }(\mathrm{n}=16)\end{array}$ & $\begin{array}{l}\text { G1: } 58.3 ; 72 \\
\text { G2: } 57.0 ; 75\end{array}$ & $\mathrm{~N} / \mathrm{S}$ & $\begin{array}{l}\text { Mental health: } \\
\text { - Salivary cortisol level (salivary } \\
\text { collection) } \\
\text { - Self-reported mood (Positive and } \\
\text { Negative Affect Schedule) }\end{array}$ & $\begin{array}{l}\text { Cortisol decreased from post- } \\
\text { stressor to post-activity in both } \\
\text { groups, but to a greater extent in G1 } \\
\text { than in G2 (-1.45 vs }-0.79 \text { nmol/L). } \\
\text { Positive mood increased from post- } \\
\text { stress to post-activity by } 9.2 \% \text { in } \mathrm{G} 1 \\
\text { participants. No change in G2 } \\
\text { participants. }\end{array}$ \\
\hline $\begin{array}{l}\text { Young et al. } \\
(2020)^{44}\end{array}$ & \begin{tabular}{c|} 
Zurich, \\
Switzerland
\end{tabular} & $\begin{array}{l}\text { Cross-sectional, } \\
\text { random } \\
\text { multiframe } \\
\text { sample, } \\
\text { comparison } \\
\text { group }\end{array}$ & $\begin{array}{l}\mathrm{n}=301 \text { adults: } \\
\text { G1: allotment gardeners }(\mathrm{n}= \\
\text { 108) } \\
\text { G2: home gardeners }(\mathrm{n}= \\
\text { 193) }\end{array}$ & $\begin{array}{l}\text { G1: } 59 ; 48 \\
\text { G2: } 54 ; 67\end{array}$ & $\begin{array}{l}\text { Mean time spent in } \\
\text { the garden: } 17.6 \\
\text { days/month }\end{array}$ & $\begin{array}{l}\text { Mental health: } \\
\text { - Self-reported restoration } \\
\text { (1-item Q) } \\
\text { • Perceived restorativeness } \\
\text { (Perceived Restorativeness Scale) } \\
\text { • Garden-related stress } \\
\text { (1-item Q) }\end{array}$ & $\begin{array}{l}\text { Participants in G1 had higher level } \\
\text { of perceived restorativeness than G2 } \\
\text { participants ( } 4.72 \pm 0.47 \text { vs } 4.28 \pm \\
0.79) \text {, which, in turn, was associated } \\
\text { with higher level of restoration. G1 } \\
\text { participants reported lower levels of } \\
\text { garden-related stress than G2 } \\
\text { participants ( } 2.15 \pm 1.23 \text { vs } 2.54 \pm \\
1.05) \text {. }\end{array}$ \\
\hline
\end{tabular}




\begin{tabular}{|c|c|c|c|c|c|c|c|}
\hline $\begin{array}{l}\text { Zick et al. } \\
(2013)^{45}\end{array}$ & $\begin{array}{l}\text { Salt Lake } \\
\text { City, UT, } \\
\text { USA }\end{array}$ & $\begin{array}{l}\text { Post-test-only } \\
\text { design, } \\
\text { administrative } \\
\text { database survey, } \\
\text { comparison } \\
\text { groups }\end{array}$ & $\begin{array}{l}\mathrm{n}=13,133 \text { adults: } \\
\text { G1: community gardeners }(\mathrm{n} \\
=198) \\
\text { G2: nongardener neighbors ( } \mathrm{n} \\
=12,552) \\
\text { G3: nongardener siblings }(\mathrm{n}= \\
\text { 316) } \\
\text { G4: nongardener spouses }(\mathrm{n}= \\
\text { 67) }\end{array}$ & $\begin{array}{l}\text { Middle 40s to } \\
\text { early 50s; } 61.1\end{array}$ & $\begin{array}{l}>1 \text { year of gardening } \\
\text { between } 1995 \text { and } \\
2010\end{array}$ & $\begin{array}{l}\text { Anthropometric outcomes: } \\
\begin{array}{l}\text { BMI (self-reported height and } \\
\text { weight })\end{array}\end{array}$ & $\begin{array}{l}\text { Women in G1 were } 46 \% \text { less likely } \\
\text { to be overweight or obese than their } \\
\text { female neighbors (G2). Men in G1 } \\
\text { were } 62 \% \text { less likely to be } \\
\text { overweight or obese than their male } \\
\text { neighbors (G2), and } 37 \% \text { less likely } \\
\text { than their siblings (G3) to be } \\
\text { overweight or obese. No difference } \\
\text { in BMI between G1 and G4. }\end{array}$ \\
\hline
\end{tabular}

Abbreviations: BMI, body mass index; BRFSS, Behavioral Risk Factor Surveillance System; EFNEP, Expanded Food and Nutrition Education Program; GP, general

practitioner; IPAQ, International Physical Activity Questionnaire; NS, not significant; Q, questionnaire; SF-36, short form-36; SQUASH, Short Questionnaire to Assess

Health Enhancing Physical Activity; WHO-5, World Health Organization-Five Well-Being Index.

${ }^{a}$ Only differences that were statistically significant are described. 
Table 3. EPHPP Quality Assessment of included Studies

\begin{tabular}{|c|c|c|c|c|c|c|}
\hline & Selection bias & Study design & Confounders & Blinding & Data collection $^{\mathrm{a}}$ & $\begin{array}{c}\text { Withdrawals and } \\
\text { drop-outs }\end{array}$ \\
\hline Alaimo et al. $(2008)^{34}$ & Weak & Weak & Strong & Moderate & Strong & $\mathrm{n} / \mathrm{a}$ \\
\hline Alaimo et al. $(2010)^{33}$ & Moderate & Weak & Strong & Weak & Strong & $\mathrm{n} / \mathrm{a}$ \\
\hline Algert et al. $(2016)^{35}$ & Weak & Weak & Weak & Weak & Moderate & $\mathrm{n} / \mathrm{a}$ \\
\hline Booth et al. $(2018)^{31}$ & Weak & Weak & Moderate & Weak & Moderate & $\mathrm{n} / \mathrm{a}$ \\
\hline Comstock et al. $(2010)^{36}$ & Weak & Weak & Strong & Moderate & Strong & $\mathrm{n} / \mathrm{a}$ \\
\hline Hawkins et al. $(2011)^{37}$ & Weak & Weak & Weak & Weak & Strong & $\mathrm{n} / \mathrm{a}$ \\
\hline Litt et al. $(2011)^{38}$ & Weak & Weak & Strong & Moderate & Strong & $\mathrm{n} / \mathrm{a}$ \\
\hline Litt et al. $(2017)^{39}$ & Weak & Weak & Strong & Moderate & Moderate & $\mathrm{n} / \mathrm{a}$ \\
\hline Martin et al. $(2017)^{40}$ & Weak & Weak & Weak & Weak & Moderate & $\mathrm{n} / \mathrm{a}$ \\
\hline Mourão et al. $(2018)^{41}$ & Weak & Weak & Weak & Weak & Strong & $\mathrm{n} / \mathrm{a}$ \\
\hline Soga et al. $(2017)^{42}$ & Weak & Weak & Strong & Weak & Strong & $\mathrm{n} / \mathrm{a}$ \\
\hline Van den Berg et al. $(2010)^{32}$ & Weak & Weak & Strong & Weak & Moderate & $\mathrm{n} / \mathrm{a}$ \\
\hline Van den Berg et al. $(2011)^{43}$ & Weak & Strong & Strong & Weak & Strong & Strong \\
\hline Young et al. $(2020)^{44}$ & Weak & Weak & Strong & Weak & Strong & $\mathrm{n} / \mathrm{a}$ \\
\hline Zick et al. $(2013)^{45}$ & Moderate & Moderate & Moderate & Moderate & Moderate & Strong \\
\hline
\end{tabular}

Abbreviation: n/a, not applicable.

${ }^{\text {a }}$ Studies using half or more valid and reliable tools were rated as strong. Studies using less than half of valid and reliable tools were rated as moderate 
